Revta brasil. Bot., São Paulo, V.23, n.1, p.27-35, mar. 2000

\title{
The developmental anatomy of the subterranean system in Mandevilla illustris (Vell.) Woodson and M. velutina (Mart. ex Stadelm.) Woodson (Apocynaceae)
}

\author{
BEATRIZ APPEZZATO-DA-GLÓRIA ${ }^{1,3}$ and MARIA EMÍLIA MARANHÃO ESTELITA ${ }^{2}$
}

(received: July 30, 1998; accepted: September 30, 1999)

\begin{abstract}
The developmental anatomy of the subterranean system in Mandevilla illustris (Vell.) Woodson and $M$. velutina (Mart. ex Stadelm.) Woodson (Apocynaceae)). Two species of Mandevilla from the savanna area of São Paulo State, Brazil were studied. These species have been prescribed as folk medicine as infusions or alcoholic extracts of the underground system for treatment of venomous snake bites. To explain the morphological nature of such a system, its ontogeny was described to determine which parts are involved in its formation. In both Mandevilla species examined, the underground system consists of a xylopodium whose basal region joins a tuberous root.
\end{abstract}

RESUMO - (O desenvolvimento anatômico do sistema subterrâneo em Mandevilla illustris (Vell.) Woodson e M. velutina (Mart. ex Stadelm.) Woodson (Apocynaceae)). Foram estudadas duas espécies de Mandevilla que ocorrem em áreas de campos cerrados do Estado de São Paulo, Brasil. Essas espécies têm sido prescritas na medicina popular como extrato alcoólico ou infusões do sistema subterrâneo para o tratamento de picadas de cobras venenosas. Para explicar a natureza morfológica de tal sistema a sua ontogênese é descrita visando determinar quais partes estão envolvidas na sua formação. Em ambas as espécies examinadas, o sistema subterrâneo consiste de um xilopódio cuja região basal une-se à uma raiz tuberosa.

Key words - Underground organs, xylopodium, Mandevilla, Apocynaceae

\section{Introduction}

According to Brazilian traditional medicine, the crude extract of underground organs from Mandevilla illustris and M. velutina (Apocynaceae), is recommended for treatment of venomous snake bites. Their medicinal potential has been demonstrated by Calixto et al. (1987).

These herbaceous plants are natives of tropical savannas (campos and campos cerrados in Brazil). They have to endure a long-lasting dry season (4-6 months). During this time, aerial shoots die and sprout again only during the next rainy period, which is also the flowering season. Apart from drought, another important factor in the life cycle of these

1. Departamento de Ciências Biológicas, Escola Superior de Agricultura 'Luiz de Queiroz', Universidade de São Paulo, Caixa Postal 09, 13418-900 Piracicaba, São Paulo, Brasil.

2. Departamento de Botânica, Instituto de Biociências, Universidade de São Paulo, Caixa Postal 11461, 05422-970 São Paulo, Brasil.

3. Corresponding author: bagloria@carpa.ciagri. usp.br species is fire, which every year sweeps the major part of the campo region burning off the aerial portions of the plant cover. With the coming of rain, new buds spring from the upper parts of the subterranean organs (Rizzini \& Heringer 1961).

These savanna plants need special study not only because of their reputed medicinal properties but also for their valuable applications to ecological studies. Besides information on their anatomy is very rare. The aim of this study was to investigate the nature of the subterranean organs of these species and to apply correct terminology. Sometimes the term xylopodium is used (Ferri 1969), or rhizome (Calixto et al. 1987) or tuberous root (Woodson 1933) to describe the underground structures. Neither the organographical characters, nor the ontogeny of these structures have been described in the literature.

\section{Material and methods}

Seeds and shoots of Mandevilla illustris (Vell.) Woodson and M. velutina (Mart. ex Stadelm.) Woodson were collected from the savanna (Cerrado) area at the Experimental Station of Itirapina, São Paulo State, Brazil. Seeds were germinated on moistened paper in Petri dishes 
kept under room temperature conditions. The seedlings were transplanted to pots of sand from the natural habitat of the species. Seedlings were harvested at different times and portions of the hypocotyl and root, at different stages of development up to the mature stage, were excised and fixed in formalin acetic alcohol (FAA 50) (Sass 1951). The samples were dehydrated in serial concentrations of ethanol, embedded in paraffin, transverse and longitudinal serial sectioned, 8-14 $\mu \mathrm{m}$ thick and stained in safranin and fast-green, following the technique of Sass (1951). Additionally, tissues from underground organs of 10 adult plants of each species were sectioned on a rotary microtome and stained in congo red and iodine green according to Dop \& Gautié (1928).

\section{Results}

General features of the subterranean system - In both species of Mandevilla, the subterranean system is made up of a vertically orientated axis in the soil (figures 1, 7-9). The upper portion (figure 7, Xy) is cylindrical, thin, woody and 5-18 cm long and 1$3 \mathrm{~cm}$ wide. It is situated superficially and new shoots arise from it periodically throughout its life cycle. The lower portion is variable in shape: fusiform, napiform or irregularly-spherical (figure 7, Tr), but it is always tuberous, soft and watery. It is $14-26 \mathrm{~cm}$ long and $10-14 \mathrm{~cm}$ wide (widest point) in M. velutina and 30-40 cm long and $15-23 \mathrm{~cm}$ wide in M. illustris. The diameter is wider in M. illustris because the lateral roots produced by the tuberous portion frequently undergo tuberization (figure 8 , arrow). The surface is irregular because of callus-like protuberances.

Root primary differentiation - Roots of both Mandevilla species are normally tetrarch (figure 2), but occasionally triarch, pentarch and hexarch. In all cases there is complete centripetal development of the primary xylem. Groups of phloem cells alternate with the primary xylem poles. The pericycle is uniseriate and can undergo divisions which produce lateral roots. The parenchymatous cortex is limited centripetally by a well-defined endodermis and centrifugally by the exodermis which has some thickwalled cells (figure 2). This layer is coverved by a uniseriate epidermis.

Ontogenesis of the tuberous roots (lower portion) The tuberization process occurs early in root growth, when roots are approximately $1 \mathrm{~mm}$ in diameter, that is, three months after planting (figure 1). The beginning of the anatomical events in secondary thickening are similar to those in a typical root. The initiation of the vascular cambium in most cases preceedes the complete development of the primary xylem (figure 3). Cambium initials appear first at the inner parenchymatous zone between xylem and phloem (figure 3 ) and are connected to form a continuous and irregular cylinder through division of the pericycle (figure 4). Subsequent cambial activity leads to the production of secondary vascular tissues with large amounts of parenchyma cells. Such meristematic activity results in an enlargement of the axis. In accommodating the widening circumference of the vascular system, cells of the cortex divide anticlinally and expand (figure 5). At the same time, the exodermis undergoes periclinal divisions producing a superficial periderm (figure 5) that replaces the protective function of the epidermis. Thus continued growth and differentiation give rise to a large fleshy root. The tuberization process is always initiated at the ramification region of the primary root (figure 9, $\mathrm{Rr}$ ), and it may reach into various levels depending on the specimen (figure 9). In some cases it may reach into the transition region and the hypocotyl base.

In both species, from early stages of development, the hypocotyl is clearly distinct from the radicle because the very short transition region is morphologically characterized by a constriction. The largest part of the hypocotyl has essentially cauline structure (figure 14). In some specimens, the hypocotyl constitutes, comparatively, a very small part of the entire tuberous structure.

The mature tuberous roots - The development of tuberous roots occurs through the activity of the vascular cambium and does not involve the occurrence of anomalous meristematic activity. The amount of secondary vascular tissues produced is greater in the upper than in the lower portion of the tuberous root. In the mature tuber, the periderm (figure 10) is produced and maintained by an active phellogen throughout the process of tuberization. Like the xylem, the secondary phloem includes large amounts of parenchyma (figures 11-12). Laticiferous cells occur in this tissue and are distinguished from cells of the surrounding tissue by their greater length (figure 13). 


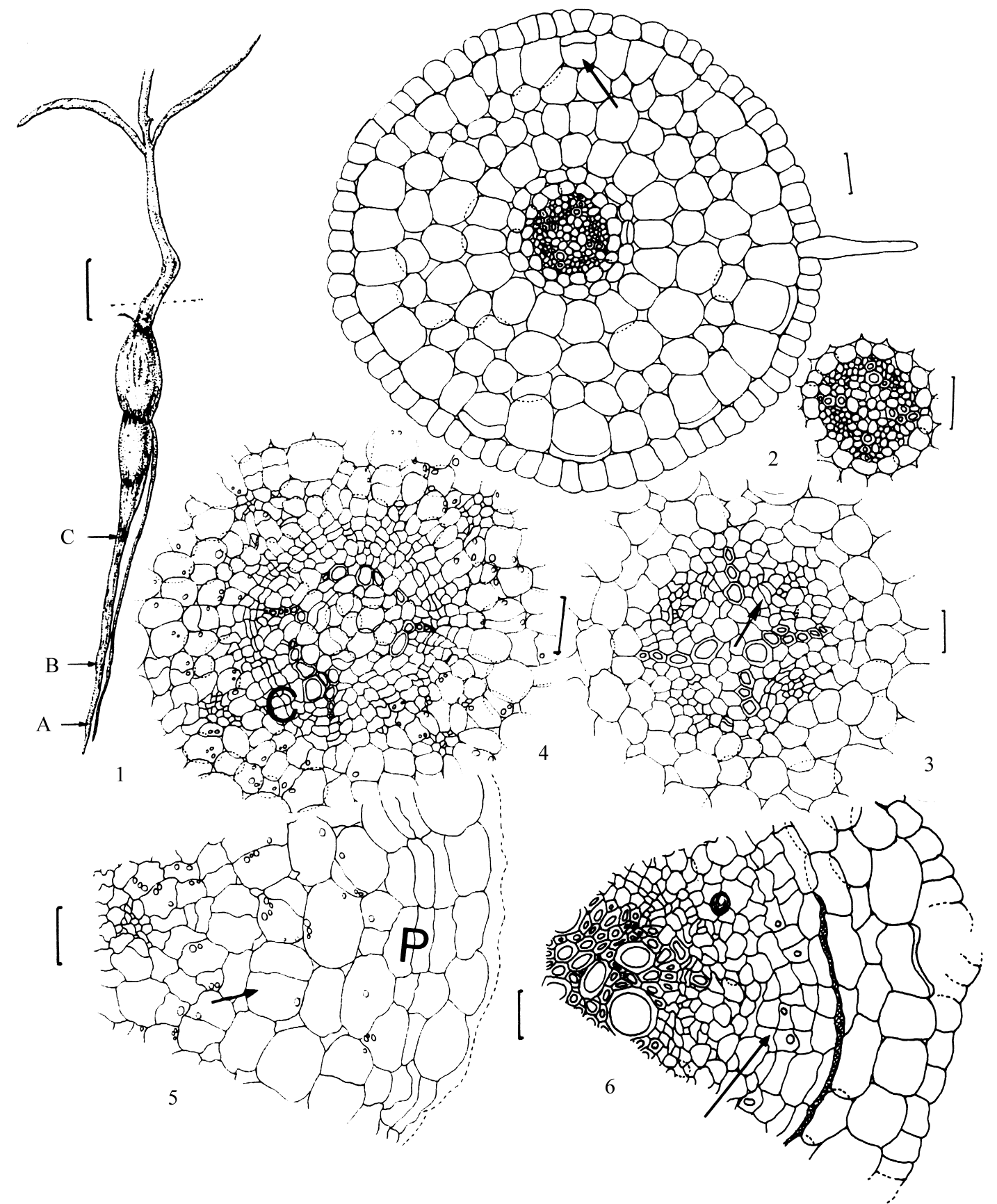

Figures 1-6. Mandevilla spp. 1. Drawings of the seedling (three months old) and of its root in transverse sections (arrowhead levels). Bar $=500 \mu \mathrm{m}$. 2. Root primary differentiation (level A) showing exodermis (arrow) and the detail of the vascular cylinder. Bar $=20 \mu \mathrm{m}$. 3. Cambium initials (arrow) laid down separating the xylem from the phloem (level B). Bar $=20 \mu \mathrm{m}$. 4. Vascular cambium (C) continuous (level C). Bar $=40 \mu \mathrm{m}$. 5. Anticlinal divisions (arrow) of the cortex cells and periclinal divisions of the exodermis originating the periderm $(\mathrm{P})$, (level C). Bar $=40 \mu \mathrm{m}$. 6 . Transection of the secondarily thickened non-tuberous roots. The secondary xylem is heavily lignified and the phellogen (arrow) is produced through division of the single-layered pericycle. Bar $=230 \mu \mathrm{m}$. 


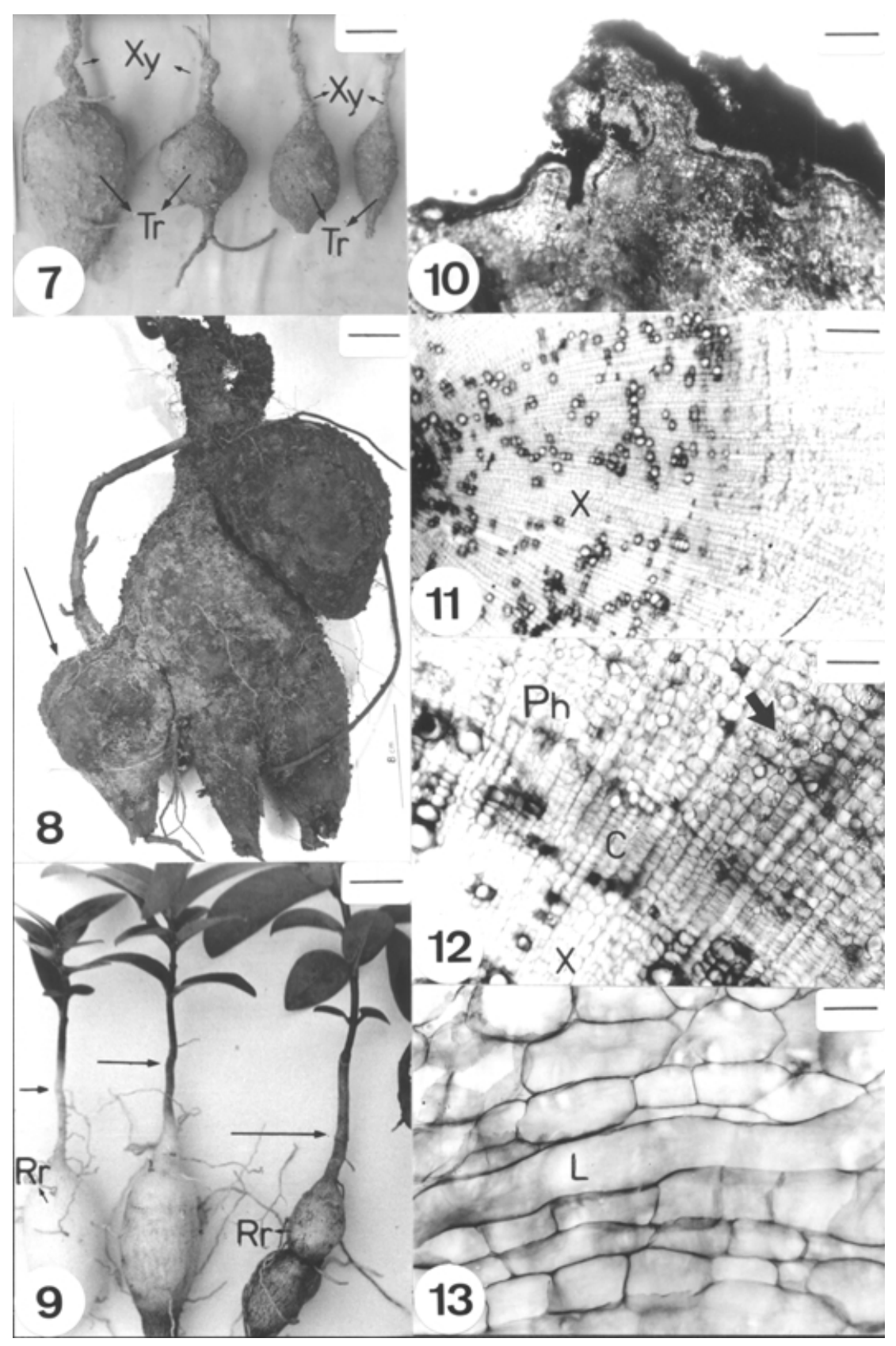

Figures 7-9. Subterranean system of Mandevilla velutina. The xylopodia (Xy) are cylindrical and the tuberous roots (Tr) are variably shaped. $\mathrm{Bar}=6.3 \mathrm{~cm}$. 8. Subterranean system of $M$. illustris. The tuberous root exhibits dilation in some lateral roots (arrow). Bar $=4 \mathrm{~cm}$. 9. Young plants of M. velutina (4 months old). The shoot-root transition region can be morphologically discerned by a constriction (arrows). Notice that tuberization is conspicuous at the ramification region $(\mathrm{Rr})$ of the primary root, and may reach into different areas depending on the specimen. Bar $=740 \mu \mathrm{m}$.

Figures 10-13. Transections of mature roots. 10. Periderm. Bar $=400 \mu \mathrm{m}$. 11. General view of the xylem tissue $(\mathrm{X})$ with large amount of parenchyma cells. Bar $=400 \mu \mathrm{m}$. 12. Detail of the xylem tissue $(\mathrm{X})$, vascular cambium $(\mathrm{C})$ and phloem $(\mathrm{Ph})$. Notice some phloem parenchyma cells storing starch (arrow). Bar $=150 \mu \mathrm{m} \mathrm{13}$. A laticiferous cell (L) among phloem parenchyma cells. Bar $=90 \mu \mathrm{m}$. 
Non-tuberous roots - Both portions of the subterranean system produce lateral roots (figure 8 ). Their primary differentiation follows the same pattern as described previously. But in secondarily thickened non-tuberous roots $(2,0-5,0 \mathrm{~mm}$ diameter $)$, the vascular cambium produces few parenchyma cells so the secondary xylem is heavily lignified (figure 6). The phellogen is produced through division of the single-layered pericycle (figure 6). During periderm formation, cortical cells and endodermis become disorganized and crushed and are ultimately eliminated along with the epidermis.

Xylopodium (upper portion) - The xylopodium originates from the hypocotyl and has a predominantly cauline structure (figures 14-16, 23). But, in some specimens, the shoot-root transition region and the proximal portion of the main root (figures 17 and 24) may be included depending on the tuberization

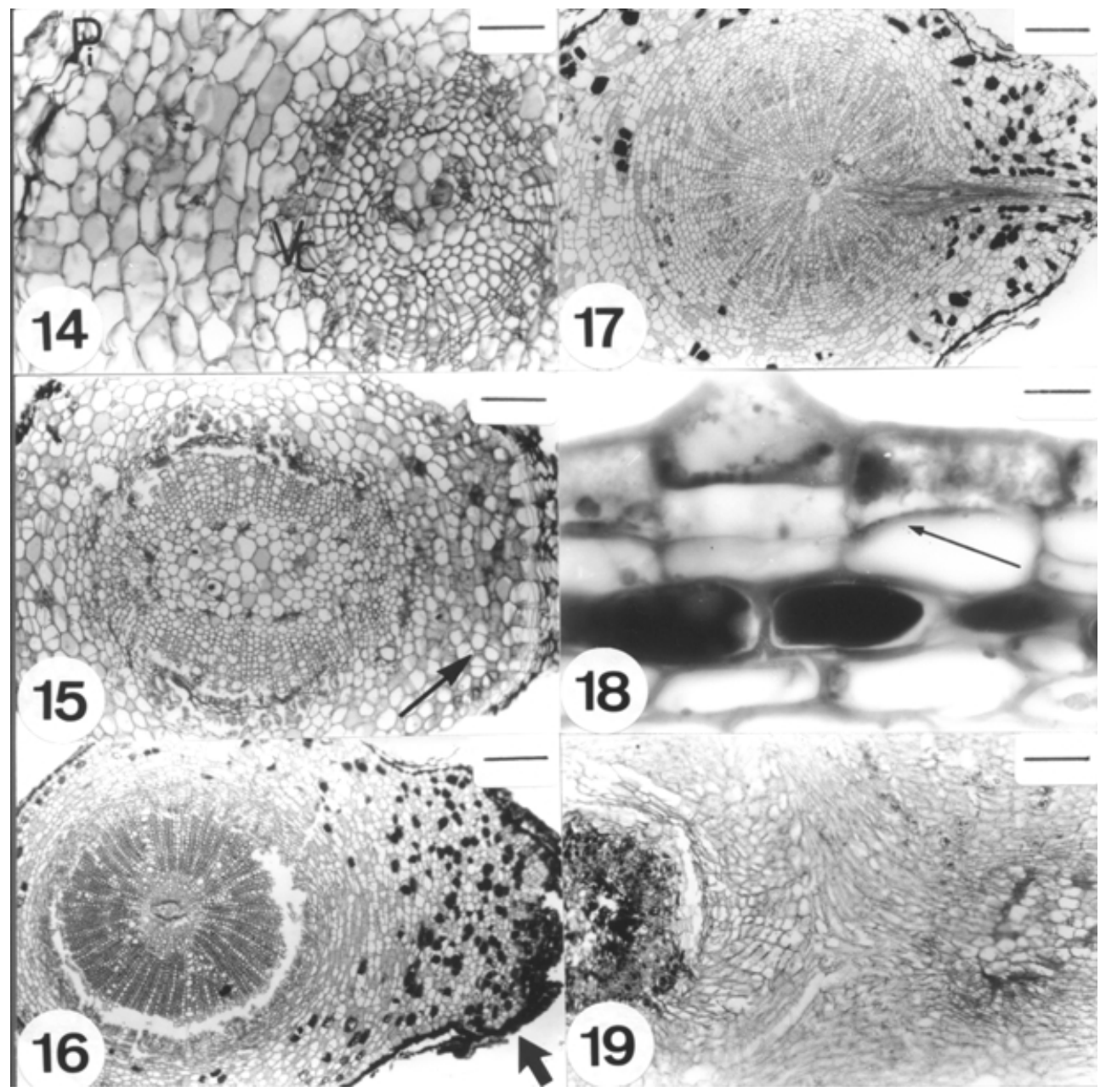

Figures 14-19. Transections of the hypocotyl and the proximal portion of the main root (16) during the early stages of xylopodium ontogeny in Mandevilla. 14. The hypocotyl has cauline structure and the initiation of the vascular cambium $(\mathrm{Vc})$ in most cases occurs at the same time as the phellogen initiation $(\mathrm{Pi})$. Bar $=60 \mu \mathrm{m}$. 15. As the cambium produces secondary vascular tissues, the periclinal and anticlinal divisions of the cortical cells are intensified (arrows). Bar $=120 \mu \mathrm{m}$. 16. A callus-like structure (arrow) can be seen on the surface of very young xylopodium (seven months old). Bar $=300 \mu \mathrm{m}$. 17. Notice the lateral root emerging through the callus-like structure. $\mathrm{Bar}=300 \mu \mathrm{m}$. 18. Epidermis undergoes periclinal divisions giving rise to the phellogen (arrow). Bar $=12 \mu \mathrm{m}$. 19. Natural self-grafting of the two shoots. Bar $=120 \mu \mathrm{m}$. 


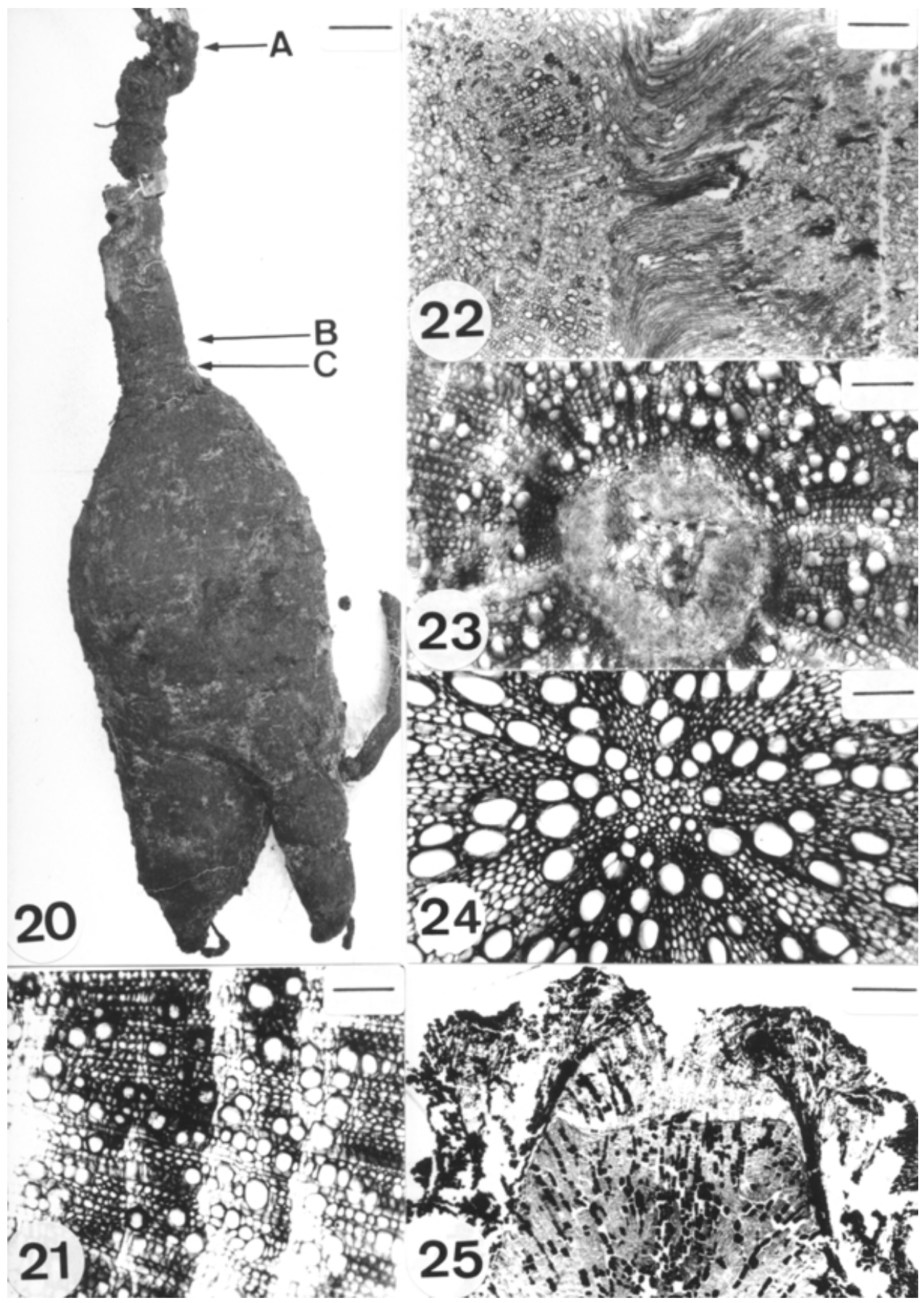

Figures 20-25. Subterranean system of M. illustris. Levels A-C in figure $20(\mathrm{Bar}=3.1 \mathrm{~cm})$ indicate the transections shown in figures 21 to 25.21 . The xylem is highly lignified and exhibits false annual rings. Bar $=150 \mu \mathrm{m} .22$. Natural self-grafting of two stems (level A). Bar $=300 \mu \mathrm{m}$. 23. Cauline structure of the xylopodium (region between levels A and B). Bar $=120 \mu \mathrm{m}$. 24. Radicular structure of the xylopodium showing highly lignified xylem. (level C). Bar $=150 \mu \mathrm{m}$. 25. Replacement of the periderm can affect the callus-like structure that may be eliminated or ruptured. Bar $=300 \mu \mathrm{m}$. 
process described previously. In both species, the hypocotyl structure is characterized by an uniseriate epidermis, followed internally by the parenchymatous cortex whose innermost layer accumulates starch. Arrangement of the vascular tissues is bicollateral and the cylinder is almost continuous. At the early stages of xylopodium ontogenesis, the epidermis undergoes periclinal divisions giving rise to the phellogen (figure 18), and some cortical cells undergo anticlinal divisions and expand tangentially. Initiation of the phellogen in most cases occurs at the same time as the formation of the vascular cambium (figure 14). As the cambium produces secondary vascular tissues, periclinal and anticlinal divisions intensify in the cortex (figure 15, arrow), and the diameter of the organ begins to increase. Cambium activity here differs from that in the tuber portion. It produces phloem with a lower proportion of thinwalled parenchyma cells than in the tuber and the secondary xylem is highly lignified (figure 16). As development proceeds, a callus-like structure can be seen on the surface of very young xylopodia (seven months old) (figure 16, arrow). This structure consists of parenchyma cells externally delimited by the periderm. Sometimes the structure is related to the emerging lateral root (figure 17). As the first shoot dies, another replaces it. During development, successive shoots may undergo self-grafting (figure 19), so that, in adult xylopodia there is often more than one axis of symmetry (figure 22). In the mature xylopodium (figure 20), secondary vascular tissues have fewer parenchyma cells than tuberous roots and lignification of the xylem increases (figures 21-24), and it is possible to see annual ring-like parts (figure 21). The original periderm may be replaced by sequential periderms. This replacement affects the callus-like structure that may be eliminated or ruptured (figure 25).

\section{Discussion}

The two Mandevilla species can be distinguished one from the other by subterranean system due to tuberization of some lateral roots in M. illustris. Other authors have pointed out the diagnostic value of underground organ morphology (Estelita-Teixeira 1982, Pate \& Dixon 1982). This feature is very important because during the 4-month shootless period, they can only be recognized by their underground organs.

Based on the present study, the terminology that should be applied to the subterranean system is $\mathrm{xy}$ lopodium (upper portion) and tuberous root (lower portion). The term xylopodium was first used by Lindman (1906) for a special type of woody underground structure, present in some plants growing in the Southern herbaceous savannas of Brazil. In his description, he does not define the anatomical nature of this structure, sometimes referred to as an underground stem, either alone or jointly with roots. In fact, the ontogeny of this structure, whose the most striking feature is its gemmiferous ability (Rizzini \& Heringer 1961), is very complex. Paviani (1977) noticed that in Brasilia sickii (Compositae), very common in this kind of vegetation, the xylopodium may be considered a morphological unit but not an anatomical one. According to her, the xylopodial structure is at times cauline and at other times radicular but always with more than one axis of symmetry. In both Mandevilla species studied, the xylopodium has predominantly, a cauline structure (stem-like vascular anatomy) derived from the hypocotyl development. But, sometimes, it shows a shoot-root vascular region or even a radicular structure. These anatomical differences among the plants, and the presence of more than one axis of symmetry that results from a natural self-grafting process of the shoots, have already pointed out by Paviani (1977). This process is in accordance with the findings of Rizzini \& Heringer (1961) who noted that the loss of shoots at the end of every dry season, favours the development of xylopodia. Additionally, features similar to growth rings have been observed in the xylopodia of both species of Mandevilla and in B. sickii (Paviani 1977). These marks could indicate the seasonal development of xylopodia.

The shapes of xylopodia are very variable; they may be globose, cylindrical (as verified in Mandevilla), or even without definite form (Rachid 1947). According to Rizzini \& Heringer (1961), they are characteristically extremely hard as we have seen in Mandevilla.

Lignotubers are another kind of woody underground structure that permits a plant to sprout rapidly after fire and to reoccupy burnt areas (Trabaud 1987). But, unlike xylopodia, lignotubers are storage 
organs supplied with protected dormant buds (Molinas \& Verdaguer 1993).

Xylopodia, on the other hand, do not have dormant buds. Plants with xylopodia are situated superficially in the driest soil, therefore, they need is be provided with water and food reserves in order to survive the dry season and to produce the aerial shoots during the rainy season (Rizzini \& Heringer 1961). This must be a factor in Mandevilla plants where the xylopodia are associated with a tuberous root. These fleshy roots are distinguished from xylopodia by the predominance in them of storage parenchyma. This tissue is lacking in xylopodia that consist mainly of woody tissues with no other storage cells than normal xylem parenchyma. While fleshy roots are soft, xylopodia are very hard (Rizzini \& Heringer 1961).

There are two groups of xylopodium-bearing plants as stated by Rizzini \& Heringer (1961). Both species of Mandevilla, conform to the second group, that is, they are plants that possess a xylopodium from the beginning of their development under cultivation or under natural conditions. It can thus be assumed that the occurrence of xylopodia is genetically determined and this presence is not merely a modification brought about by environmental conditions (Rizzini \& Heringer 1961).

In both species of Mandevilla, tuber growth and development resulted from activities of a normal cambium cylinder, as in carrot (Daucus carota) (Esau 1940) and in Oxalis (Estelita-Teixeira 1982). They do not involve the occurrence of anomalous meristematic activity. In Mandevilla, the precocious tuberization process is related to the establishment of the species in hard soil conditions and it enables the primary root to retain water helping it to persist through the dry season (Rizzini \& Heringer 1962). In carrot, the hypocotyl and the root partake in forming the fleshy organ through excessive secondary growth (Esau 1940). However, in some Mandevilla plants, the hypocotyl constitutes a comparatively small part of the entire fleshy structure. In carrot, the largest part of the hypocotyl is essentially radicular, while in Mandevilla the hypocotyl is cauline.

Our observations on xylopodium and tuber structure concur with those on the extra-tuber region of Ipomoea batatas by Wilson \& Lowe (1973) and Pachyrhizus erosus by Dabydeen \& Sirju-Charran
(1990) and supports their suggestion that tuberization is dependent on the relative predominance of lignin biosynthesis, or cell division and expansion in the course of root ontogenesis. Sirju-Charran \& Wickham (1988) also suggested that the occurrence of lignification was the major limitation to tuberization of both roots and stem of sweet potato.

Phellogen initials in tuberous roots, non-tuberous roots and in the hypocotyl of Mandevilla originate from different tissues. Waisel \& Liphschitz (1975) also have observed an abrupt change from the origin of phellogen in the epidermis to its origin in the pericycle between hypocotyl and root in Nerium oleander (Apocynaceae). The first phellogen of nontuberous roots originates deep inside the pericycle, as generally described for roots (Esau 1977). But, in tuberous roots the first periderm has subepidermal origin, probably owing to their storage function. Superficial origin allows the parenchymatous cells of the cortex, not eliminated, to store starch. In the xylopodium, the first periderm is also superficial, but it originates from epidermis of the hypocotyl. The first periderm in the xylopodium of $B$. sickii is formed partly in the epidermis and partly in subepidermal cells (Paviani 1977) and, as in Mandevilla, the xylopodia show sucessive periderms.

Acknowledgements - The authors thank the Fundação de Amparo à Pesquisa do Estado de São Paulo (FAPESP process 87/3429-1) and Professor Fernanda Bacellar for the English review of this paper.

\section{References}

CALIXTO, J.B., NICOLAU, M., PIZZOLATTI, M.G. \& YUNES, R.A. 1987. Kinin antagonist activity of compounds from Mandevilla velutina in the rat isolated uterus. British Journal of Pharmacology 91:199-204.

DABYDEEN, S. \& SIRJU-CHARRAN, G. 1990. The developmental anatomy of the root system in yam bean, Pachyrhizus erosus Urban. Annals of Botany 66:313-320.

DOP, P. \& GAUTIÉ, A. 1928. Manual de technique botanique. J. Lamarre XXII, Paris.

ESAU, K. 1940. Developmental anatomy of the fleshy storage organ of Daucus carota. Hilgardia 13:175226.

ESAU, K. 1977. Anatomy of the seed plants. John Wiley and Sons, Inc., New York. 
ESTELITA-TEIXEIRA, M.E. 1982. Shoot anatomy of three bulbous species of Oxalis. Annals of Botany 49:805-813.

FERRI, M.G. 1969. Plantas do Brasil: espécies do Cerrado. Edgard Blücher Ltda., EDUSP, São Paulo.

LINDMAN, C.A.M. 1906. A vegetação no Rio Grande do Sul. Transl. by A. Loefgren, Porto Alegre.

MOLINAS, M.L. \& VERDAGUER, D. 1993. Lignotuber ontogeny in the cork-oak (Quercus suber; Fagaceae) II. Germination and young seedling. American Journal of Botany 80:182-191.

PATE, J.S. \& DIXON, K.W. 1982. Tuberous, Cormous and Bulbous Plants; biology of an adaptative strategy in Western Australia. University of Western Australia Press, Nedlands.

PAVIANI, T.I. 1977. Estudo morfológico e anatômico de Brasilia sickii G.M. Barroso. II: Anatomia da raiz, do xilopódio e do caule. Revista Brasileira de Biologia 37:307-324.

RACHID, D.M. 1947. Transpiração e sistemas subterrâneos de vegeteção de verão dos campos cerrados de Emas. Boletim da Faculdade de Filosofia, Ciências e Letras de São Paulo 5:7-129.

RIZZINI, C.T. \& HERINGER, E.P. 1961. Underground organs of plants from some Brazilian savannas, with special reference to the xylopodium. Phyton 17:105124.
RIZZINI, C.T. \& HERINGER, E.P. 1962. Studies on the underground organs of trees and shrubs from some southern Brazilian savannas. Anais da Academia Brasileira de Ciências 34:235-247.

SASS, J.E. 1951. Botanical microtechnique. Iowa State University Press, Ames.

SIRJU-CHARRAN, G. \& WICKHAM, L.D. 1988. The development of alternative storage sink sites in sweet potato Ipomoea batatas. Annals of Botany 61:99-102.

TRABAUD, L. 1987. Natural and prescribed fire: survival strategies of plants and equilibrium in Mediterranean ecosystems. In Plant response to stress. NATO ASI Series (J. D. Tenhunen, ed.). Springer-Verlag, Berlin, v.615, p.607-621.

WAISEL, Y. \& LIPHSCHITZ, N. 1975. Sites of phellogen initiation. Botanical Gazette 136:146-50.

WILSON, L.A. \& LOWE, S.B. 1973. The anatomy of the root system in West Indian Sweet Potato (Ipomoea batatas (L.) Lam.) Cultivars. Annals of Botany 37:633-643.

WOODSON, R.E. JR. 1933. Studies in the Apocynaceae: IV The American genera of Echitoideae. Annals of Missouri Botanical Garden 20:605-627. 